\title{
Gastrointestinal complaints in runners are not due to small intestinal bacterial overgrowth
}

\author{
Kai Schommer ${ }^{1 *}$, Dejan Reljic ${ }^{1}$, Peter Bärtsch ${ }^{1}$ and Peter Sauer ${ }^{2}$
}

\begin{abstract}
Background: Gastrointestinal complaints are common among long distance runners. We hypothesised that small intestinal bacterial overgrowth $(\mathrm{SIBO})$ is present in long distance runners frequently afflicted with gastrointestinal complaints.

Findings: Seven long distance runners ( 5 female, mean age 29.1 years) with gastrointestinal complaints during and immediately after exercise without known gastrointestinal diseases performed Glucose hydrogen breath tests for detection of SIBO one week after a lactose hydrogen breath test checking for lactose intolerance. The most frequent symptoms were diarrhea $(5 / 7,71 \%)$ and flatulence $(6 / 7,86 \%)$. The study was conducted at a laboratory. In none of the subjects a pathological hydrogen production was observed after the intake of glucose. Only in one athlete a pathological hydrogen production was measured after the intake of lactose suggesting lactose intolerance.
\end{abstract}

Conclusions: Gastrointestinal disorders in the examined long distance runners were not associated with small intestinal bacterial overgrowth.

\section{Introduction}

Gastrointestinal (GI) disturbances during or immediately after exercise are common among runners [1,2]. 20-50\% of long distance runners are affected [3]. Both the upper and lower GI tract are involved. Symptoms are vomiting, nausea, bloating, heartburn and flatulence as well as watery and bloody diarrhea and anal incontinence [4]. The causative mechanisms are not completely understood. The mechanical irritation of the GI tract during running can change intestinal motility [5], additionally exercise causes a reduction of the mesenteric blood flow [6] and both may contribute to the symptoms. Both, a GI dysmotility as well as a reduced mesenteric blood flow are well known risk factors for development of small intestinal bacterial overgrowth (SIBO) $[7,8]$. Clinical manifestations of SIBO involve the upper and lower GI tract and are similar to the complaints of long distance runners. The gold standard in diagnosing SIBO consists in culture of jejunum aspirate for bacterial

\footnotetext{
* Correspondence: kai.schommer@med.uni-heidelberg.de

'Department of Internal Medicine, The University Hospital Heidelberg, Division of Sports Medicine, Im Neuenheimer Feld 410, 69120 Heidelberg, Germany

Full list of author information is available at the end of the article
}

counts, but also non-invasive hydrogen breath testing with glucose (GHBT) is well established [9-12]. We hypothesized that due to the high weekly training volume with irritation of GI motility and repeated impairment of the mesenteric perfusion SIBO is present in long distance runners with frequent GI symptoms.

\section{Methods}

Seven long distance runners (5 female, 2 male) were recruited with the help of the headcoach for long distance runners of Baden-Württemberg. Baseline characteristics are given in table 1.

We only included otherwise healthy, non-smoking long distance runners with a training experience of $\geq 5$ years and a minimum two years lasting, unexplained history of frequent GI complaints (nausea, eructation, heartburn, angina pectoris, vomiting, abdominal cramping, flatulence, diarrhea, or stitch) during or within one hour after running. "Frequent" was defined as at least every other run, and they must have had at least two of the above-mentioned symptoms. By a modified selfassessment questionnaire used in a previous study [13], the following exclusion criteria were assessed: known GI diseases, family history of bowel disease, indication that 
Table 1 baseline characteristics

\begin{tabular}{ccccccccc}
\hline subject & sex & $\begin{array}{c}\text { age } \\
\text { [years] }\end{array}$ & $\begin{array}{c}\text { body } \\
\text { mass index } \\
{\left[\mathbf{k g} / \mathbf{m}^{\mathbf{2}}\right]}\end{array}$ & $\begin{array}{c}\text { body } \\
\text { fat } \\
{[\%]}\end{array}$ & $\begin{array}{c}\text { training } \\
\text { experience } \\
\text { [years] }\end{array}$ & $\begin{array}{c}\text { weekly training } \\
\text { mileage } \\
\text { [kilometers] }\end{array}$ & $\begin{array}{c}\text { training } \\
\text { sessions } \\
\text { [/week] }\end{array}$ & $\begin{array}{c}\text { running speed at } \\
\mathbf{4} \text { mmol/l lactate threshold } \\
\text { [km/h] }\end{array}$ \\
\hline $\mathbf{1}$ & female & 25 & 19.5 & 14.1 & 6 & 120 & 10 & 16.6 \\
$\mathbf{2}$ & male & 33 & 20.6 & 8.5 & 9 & 120 & $10-12$ & 18.3 \\
$\mathbf{3}$ & male & 27 & 22.1 & 13.3 & 8 & 60 & 11 & 16.8 \\
$\mathbf{4}$ & female & 21 & 20.8 & 14.1 & 6 & 60 & $4-6$ & 13.9 \\
$\mathbf{5}$ & female & 33 & 19.8 & 15.8 & 7 & 100 & 7 & 15.6 \\
$\mathbf{6}$ & female & 38 & 21.8 & 15.3 & 17 & 60 & 6 & 13.2 \\
$\mathbf{7}$ & female & 27 & 22.1 & 20.7 & 7 & 60 & 6 & 13.7 \\
\hline
\end{tabular}

intake of special food or beverage could explain the GI complaints, intake of antibiotics or proton-pump inhibitors within one month before the study started. Table 2 summarises the GI symptoms reported in the questionnaire. Clinical examination of the abdomen including auscultation and palpation were normal. ECG at rest and during exercise and blood examinations for haemogram, ESR, Aspartate- and Alanine-transaminase, $\gamma$-glutamyltransferase, creatinine, urea and ferritine were normal. Body fat composition was determined by 3 point skin fold calipometry [14]. After preexamination, a lactose hydrogen breath test (LHBT) and at least one week later a GHBT on "Wasserstoff-Atemtest" (IFM $\mathrm{GmbH}$, Wettenberg, Germany) were performed after a 12 hour fasting period. These tests were performed in a laboratory of the division of gastroenterology where this examination is routine practice. After two measurements of baseline values for exhaled hydrogen, either $50 \mathrm{~g}$ lactose or $75 \mathrm{~g}$ glucose (both dissolved in $200 \mathrm{ml}$ of water) was applied and breath samples were analysed for hydrogen every 10 minutes for 3 hours. SIBO is suspected if a clearly recognisable hydrogen peak is present and exhaled hydrogen exceeds 20 parts per million over baseline values in both tests $[15,16]$. Late hydrogen peaks in the GHBT can be caused by a faster GI transit time for glucose and thus simulate SIBO [9]. Therefore,

Table 2 distribution of gastrointestinal symptoms

\begin{tabular}{ccccccc}
\hline symptoms & \multicolumn{2}{c}{ total } & \multicolumn{2}{c}{ during running } & \multicolumn{2}{c}{ after running } \\
\hline & $\mathbf{n}$ & $\%$ & $\mathbf{n}$ & $\%$ & $\mathbf{n}$ & $\%$ \\
\hline nausea & 0 & 0 & 0 & 0 & 0 & 0 \\
eructation & 2 & 29 & 1 & 14 & 1 & 14 \\
heartburn & 2 & 29 & 1 & 14 & 1 & 14 \\
angina pectoris & 0 & 0 & 0 & 0 & 0 & 0 \\
vomiting & 1 & 14 & 0 & 0 & 1 & 14 \\
abdominal cramping & 3 & 43 & 3 & 43 & 3 & 43 \\
flatulence & 6 & 86 & 3 & 43 & 3 & 43 \\
diarrhea & 5 & 71 & 3 & 43 & 5 & 71 \\
stitch & 1 & 14 & 0 & 0 & 1 & 14 \\
\hline
\end{tabular}

LHBT was performed as a control in the case of a positive GHBT: SIBO must also result in a positive LHBT [17], but a faster transit time for Glucose does not. Written informed consent was obtained from the subjects, and the study has been approved by the Ethics Commitee of the Medical Faculty of the University of Heidelberg.

\section{Results}

In none of the seven athletes a pathological hydrogen production after application of glucose was observed (Figure 1). In subject 3, a pathological hydrogen production was measured after intake of lactose but not after glucose, suggesting lactose intolerance. Incidentally, this athlete never had any problem after the intake of milk products. In the remaining 6 subjects, LHBT was unremarkable (Figure 2). Subject 4 reported bloody diarrhea after a marathon race two years before. At this time, gastroscopy only revealed some gastric erosions without helicobacter pylori infection whereas colonoscopy was unremarkable.

\section{Discussion}

This study does not provide evidence of SIBO as a common cause accounting for GI problems in long distance runners. All of the investigated runners were frequently afflicted with the usually reported GI symptoms in runners, but none of them showed a pathological GHBT. In the absence of an early peak in this test which could indicate SIBO, the late peak in subjects 1 and 2 in the GHBT is attributable to the passage of the glucose into the colon. This conclusion is supported by the unremarkable LHBT in both runners. The sensitivity and specificity of the GHBT in detecting SIBO was reported to be $62 \%$ and $83 \%[18,19]$. With a given prevalence of SIBO in younger adults aged 24 to 59 years of $5-10 \%$ [20], the negative predictive value of an unremarkable GHBT is $95-98 \%$. Considering the consistent negative findings in our study we conclude that SIBO is not a common cause for the GI problems of the long distance 


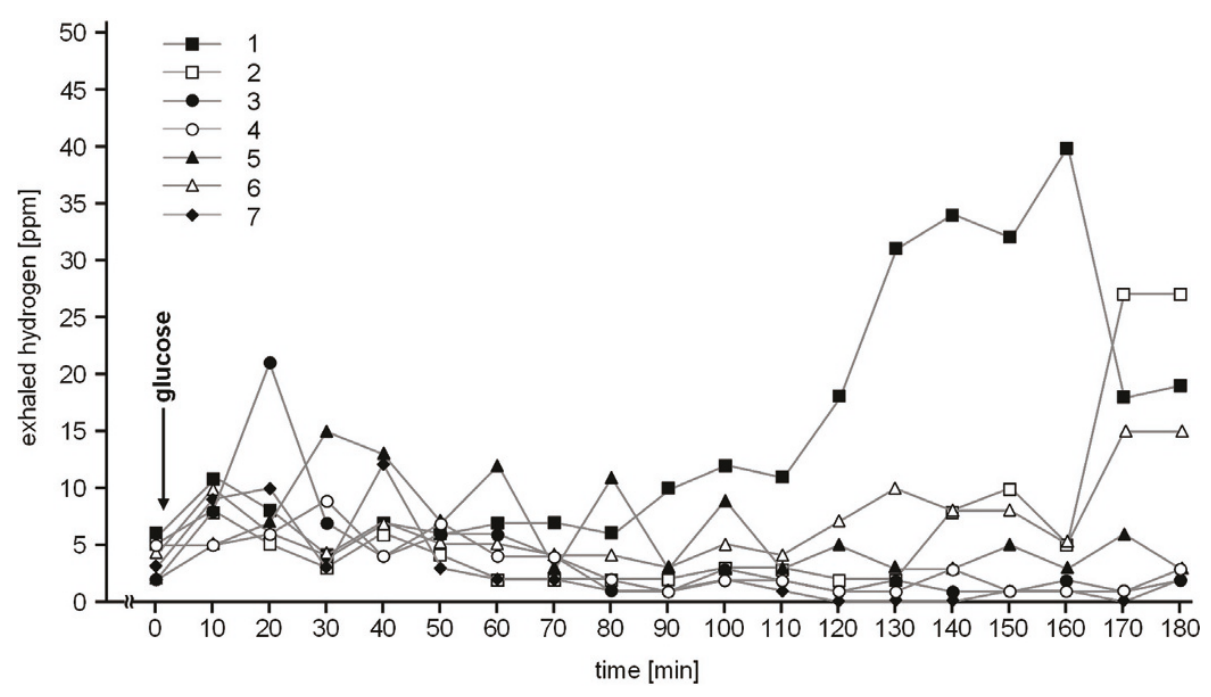

Figure 1 results of the glucose hydrogen breath test.

runner. It appears that the daily duration of the reduced mesenteric blood flow and of the mechanical GI tract concussion does not last long enough in these runners to cause SIBO. The positive LHBT in subject 3 either could be false-positive or indicates a real lactose intolerance. It is reported that lactose maldigesters can usually tolerate small amounts of lactose without symptoms [21]. This could explain why this athlete is asymptomatic except when running. The self-assessment questionnaire did not reveal the intake of lactose-containing food or dietary supplements in connection with running and thus, lactose intolerance is not the reason for the GI symptoms in this athlete.

\section{Acknowledgements}

The authors thank Christian Stang for his assistance with recruiting the subjects and Birgit Friedmann-Bette for her help in this study.

\section{Author details}

'Department of Internal Medicine, The University Hospital Heidelberg, Division of Sports Medicine, Im Neuenheimer Feld 410, 69120 Heidelberg, Germany. ${ }^{2}$ Department of Internal Medicine, The University Hospital Heidelberg, Division of Gastroenterology, Im Neuenheimer Feld 410, 69120 Heidelberg, Germany.

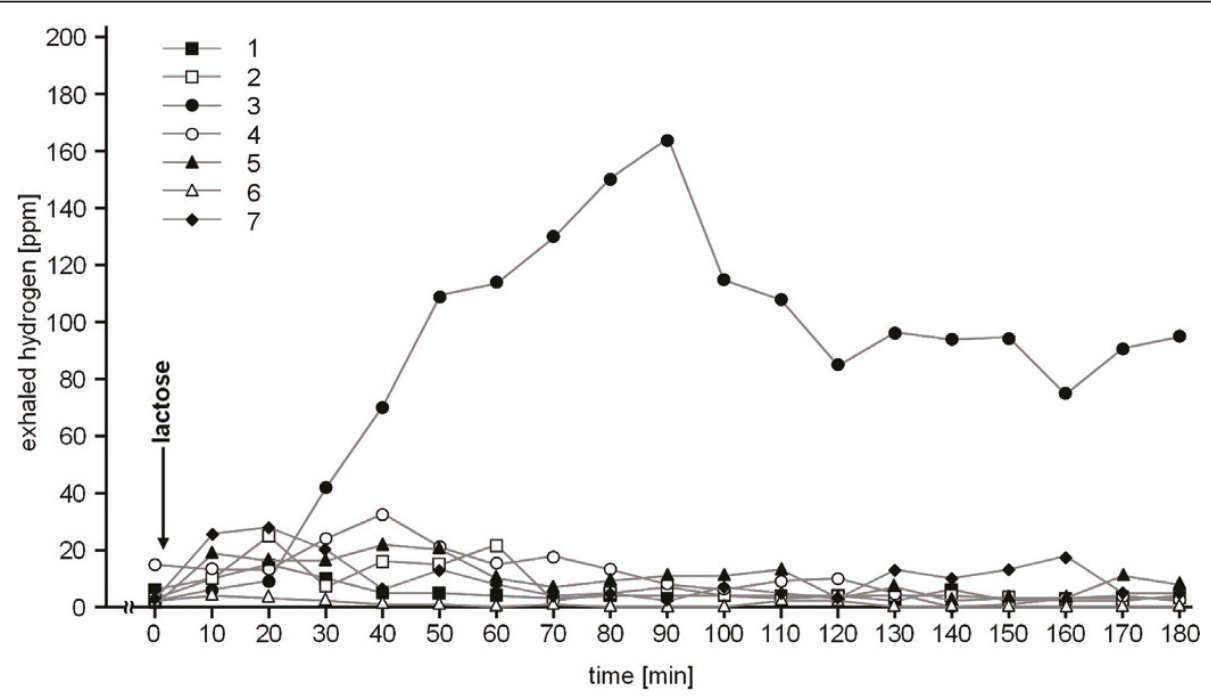

Figure 2 results of the lactose hydrogen breath test. 


\section{Authors' contributions}

KS: conception and design, acquisition, analysis and interpretation of data, drafting the manuscript; DR: acquisition and analysis of data; PB: analysis and interpretation of data, drafting of the manuscript; PS: design, acquisition, analysis and interpretation of data, drafting of the manuscript. All authors read and approved the final manuscript.

\section{Competing interests}

The authors declare that they have no competing interests.

Received: 10 February 2011 Accepted: 27 July 2011

Published: 27 July 2011

\section{References}

1. Simons SM, Kennedy RG: Gastrointestinal problems in runners. Curr Sports Med Rep 2004, 3(2):112-116.

2. Sanchez LD, Corwell B, Berkoff D: Medical problems of marathon runners. Am J Emerg Med 2006, 24(5):608-615.

3. Peters HP, Bos M, Seebregts L, Akkermans LM, van Berge Henegouwen GP, Bol E, Mosterd WL, de Vries WR: Gastrointestinal symptoms in longdistance runners, cyclists, and triathletes: prevalence, medication, and etiology. Am J Gastroenterol 1999, 94(6):1570-1581.

4. Riddoch C, Trinick T: Gastrointestinal disturbances in marathon runners. Br J Sports Med 1988, 22(2):71-74.

5. de Oliveira EP, Burini RC: The impact of physical exercise on the gastrointestinal tract. Curr Opin Clin Nutr Metab Care 2009, 12(5):533-538,

6. Perko MJ, Nielsen HB, Skak C, Clemmesen JO, Schroeder TV, Secher NH: Mesenteric, coeliac and splanchnic blood flow in humans during exercise. J Physiol 1998, 513(Pt 3):907-913.

7. Rana SV, Bhardwaj SB: Small intestinal bacterial overgrowth. Scand J Gastroenterol 2008, 43(9):1030-1037.

8. Gupta A, Dhiman RK, Kumari S, Rana S, Agarwal R, Duseja A, Chawla Y: Role of small intestinal bacterial overgrowth and delayed gastrointestinal transit time in cirrhotic patients with minimal hepatic encephalopathy. J Hepatol 2010, 53(5):849-855.

9. Simren M, Stotzer PO: Use and abuse of hydrogen breath tests. Gut 2006, 55(3):297-303.

10. Stotzer PO, Kilander AF: Comparison of the 1-gram (14)C-D-xylose breath test and the 50-gram hydrogen glucose breath test for diagnosis of small intestinal bacterial overgrowth. Digestion 2000, 61(3):165-171.

11. Rana SV, Sinha SK, Sikander A, Bhasin DK, Singh K: Study of small intestinal bacterial overgrowth in North Indian patients with irritable bowel syndrome: a case control study. Trop Gastroenterol 2008, 29(1):23-25.

12. Rana SV, Sinha SK, Lal S, Sikander A, Singh K: Small intestinal bacterial overgrowth in North Indian patients with celiac disease. Trop Gastroenterol 2007, 28(4):159-161.

13. Halvorsen FA, Lyng J, Glomsaker T, Ritland S: Gastrointestinal disturbances in marathon runners. Br J Sports Med 1990, 24(4):266-268.

14. Lohman TG: Skinfolds and body density and their relation to body fatness: a review. Hum Biol 1981, 53(2):181-225.

15. Kerlin $\mathrm{P}$, Wong L: Breath hydrogen testing in bacterial overgrowth of the small intestine. Gastroenterology 1988, 95(4):982-988.

16. Metz G, Gassull MA, Drasar BS, Jenkins DJ, Blendis LM: Breath-hydrogen test for small-intestinal bacterial colonisation. Lancet 1976, 1(7961):668-669.

17. Nucera G, Gabrielli M, Lupascu A, Lauritano EC, Santoliquido A, Cremonini F, Cammarota G, Tondi P, Pola P, Gasbarrini G, et al: Abnormal breath tests to lactose, fructose and sorbitol in irritable bowel syndrome may be explained by small intestinal bacterial overgrowth. Aliment Pharmacol Ther 2005, 21(11):1391-1395.

18. Corazza G, Sorge M, Strocchi A, Gasbarrini G: Glucose-H2 breath test for small intestine bacterial overgrowth. Gastroenterology 1990, 98(1):253-254.

19. Corazza GR, Menozzi MG, Strocchi A, Rasciti L, Vaira D, Lecchini R, Avanzini P, Chezzi C, Gasbarrini G: The diagnosis of small bowel bacterial overgrowth. Reliability of jejunal culture and inadequacy of breath hydrogen testing. Gastroenterology 1990, 98(2):302-309.

20. Parlesak A, Klein B, Schecher K, Bode JC, Bode C: Prevalence of small bowel bacterial overgrowth and its association with nutrition intake in nonhospitalized older adults. J Am Geriatr Soc 2003, 51(6):768-773.
21. Suarez FL, Savaiano DA, Levitt MD: A comparison of symptoms after the consumption of milk or lactose-hydrolyzed milk by people with selfreported severe lactose intolerance. N Engl J Med 1995, 333(1):1-4.

doi:10.1186/1477-5751-10-8

Cite this article as: Schommer et al:: Gastrointestinal complaints in runners are not due to small intestinal bacterial overgrowth. Journal of Negative Results in BioMedicine 2011 10:8.

\section{Submit your next manuscript to BioMed Central and take full advantage of:}

- Convenient online submission

- Thorough peer review

- No space constraints or color figure charges

- Immediate publication on acceptance

- Inclusion in PubMed, CAS, Scopus and Google Scholar

- Research which is freely available for redistribution

Submit your manuscript at www.biomedcentral.com/submit 